\title{
Modelling Maqasid Waqf Performance Measures in Waqf Institutions
}

\author{
Roshayani Arshad (Corresponding Author) \\ Accounting Research Institute, Universiti Teknologi MARA, \\ 40450, Shah Alam, Malaysia. \\ Tel: +603-5544 7910 Email: roshayani@salam.uitm.edu.my \\ Norzaihan Mohd Zain \\ Accounting Research Institute, Universiti Teknologi MARA, \\ 40450, Shah Alam, Malaysia. \\ Tel: +6016-6681443 Email: jihanzain@yahoo.com \\ Sharina Tajul Urus \\ Faculty of Accountancy, Bandar Puncak Alam, \\ 42300 Kuala Selangor, Selangor, Malaysia \\ Tel: +603-32587440 Email: sharina675@salam.uitm.edu.my \\ Ahmed Chakir \\ IbnZohr University \\ BP, 37/S,Hay Salam, Agadir,Morocco \\ Tel: +212-661628247 Email: Ahmed.chakir@uiz.ac.ma
}

\begin{abstract}
Waqf is viewed as one of the potential mechanisms to stimulate the economic and social development of the society. However, despite the great contributions from waqf, the potential and benefits of waqf have not been fully capitalised. Acknowledging such issue, there is a need for the institutions responsible to manage waqf assets to enhance their performance in fulfilling their accountability towards relevant stakeholders, consistent with maqasid waqf perspective. Therefore, the aim of this study is to explore the indicators of performance measurement for waqf institutions based on the non-profit organization, given some similarity to non-profit organizations, and maqasid waqf perspectives. To achieve the research objective, this study will conduct two stages of data collection and analysis: reviews of the literature and semi-structured interview with waqf managers and Islamic scholar. The outcome of the study will be in the form of a proposed performance measurement model, in
\end{abstract}

line with maqasid waqf that can be adapted by waqf institutions in assessing their performance as well as discharging their accountability and enhancing the value creation of waqf assets for the Ummah.

Keywords: Waqf;, Maqasid Waqf; Performance Measurements

\section{Introduction}

Waqf, is one amongst the various potential Islamic economic instruments which can stimulates the socio-economic for the society. In strengthening the role of waqf assets as an important contribution to the socio-economic development in Malaysia, the government has allocated RM257 million and RM72.76 million under the 9th and 10th Malaysian Plan (RMK) respectively to finance the development of waqf properties (Bernama, 2011). Under the 11th RMK which stretches from the years 2016 to 2020, the Government has undertaken a specific policy to enhance the Bumiputera Economic 
Community (BEC) opportunities to increase wealth ownership through the development of waqf assets while retaining Bumiputera ownership (Chin, 2015). Hence, it is crucial that waqf institutions are effectively managed in mobilising the development and value creation of waqf assets.

However, there are growing concerns that the waqf institutions have played a minimal role in managing the waqf assets effectively and in turn contribute to the economic growth of the country (Isamail, Rosele, \& Ramli, 2015). In this context, many waqf land are under-developed even though they are in very strategic areas (Ahmad \& Muhamed, 2011). For example, there are 30,000 hectares of waqf land in Malaysia, but only 12\% (3,600 hectares) of the land have been developed (Omar, 2016). In the year 2015, the National Audit Department has audited the management of waqf properties by the waqfinstitutions in Malaysia and found that the properties were not being managed properly and effectively by the institutions. The unsatisfactory condition and management of waqf properties infers that the waqf institutions are not effectively and efficiently managed since waqf properties represent the main component of the institution's responsibilities (Auditor General's Report, 2014).

In optimising the contributions of waqf assets, the trustee or mutawalli of the assets must be equipped with relevant information to guide and make effective decision-making processes in assessing whether the assets have been managed efficiently and shariah compliant. However, there is lack of appropriate performance measures in guiding waqf institutions to perform effectively and achieve maqasid waqf. Concurrently, appropriate information on the performance measures of waqf institutions can be used as a mechanism to enhance and gain support from the public to continue investing in waqf properties. Failure to do so can result in diminishing pool of waqf assets with negative impact on the socio-economic development of the Ummah. This implies that it is important for waqf institutions to have some guidance in assessing their role as mutawalli effectively in fulfilling socio-economic objective and maqasid waqf. Hence, performance measurement model incorporating maqasid waqf elements is a crucial tool that can guide waqf institutions to achieve their maqasid and missions.

Therefore, the objective of this study is to establish a holistic performance measurement model to fill the current gap in the literature and practice that can be adapted by waqf institutions in assessing their performance and also as a benchmark for improvement. In establishing the model, the study will explore the indicators of performance measurement for waqf institutions based on the non-profit organization and maqasid waqf perspectives.

The remainder of this paper is organized as follows. The second section discusses the literature review on waqf, performance measurement and maqasid waqf. The third section explains the research methodology employed in this study. Research findings are reviewed and discussed in section four, and the final section highlights the conclusion and gap for future research.

\section{Literature Review}

\section{Waqf}

Waqf in general refers to confinement or detention. In the Islamic jurisprudence, it means "withholding or immobilizing an asset and mobilizing or releasing its proceeds" (Sabiq, 2004, p. 1069). Withholding means that the assets cannot be sold or disposed of in any way, releasing the proceed means that the benefit or usufruct can be obtained from the asset without consuming it, need to be spent in the way as permitted by Allah s.w.t (Kahf, 2003). Waqf is also known as a perpetual endowment created in the form of property, money or other items for charitable or religious purposes and the usufruct (benefit) is confined to the society as a whole or for a specific segment of society in 
need (Hassan \& Shahid, 2010). This religious act is one of the commendable forms of charity and repeatedly encouraged and mentioned in the Quran and Sunnah.

\section{"The parable of those who spend their wealth in Allah's way is as the parable of grain; it grows seven ears, and in each ear, there are a hundred grains. Allah gives manifold increase to whom He wills. And Allah is All-Embracing, All-Knowing”. (Al Baqarah: 261)}

From a Hadith of Abu Hurairah r.a. who reported that Rasulullah s.a.w said:

"When the son of Adam dies, his deeds are cut of except in three: perpetual charitable donation and useful knowledge that is made good use of it and the pious son who prays for him. " Narrated by Muslim

Given these explanations, the role of waqf can be portrayed as the mechanism for the social and economic development of Muslim society continue throughout the Islamic history until today (Laldin \& Hafas, 2013). Initially waqf was dedicated to creating and maintaining religious institutions such as mosques or other places of worships, but later, the role of waqf was extended to other socio-economic welfare of the society such as building and maintaining universities, schools, hospitals, graveyards, orphanages, and others (Mahamood, 2000).

The perpetuity of waqf implies that waqf property needs to be preserved and the benefits can be gained without consuming it (Kahf, 2003). When a waqif (a person who waqf his assets) surrenders his properties as waqf, the properties are no longer his as the ownership of any waqf property belongs to Allah s.w.t. Therefore, an administrator or trustee (mutawalli or nazer) has to be appointed to manage the properties in order to ensure perpetuity and that the benefits will be continually disseminated to the beneficiaries.

\section{Waqf Institutions in Malaysia}

In Malaysia, the institutions that are given the authority to manage waqf as elected by the Federal Constitution and State Enactments are the State Islamic Religious Councils (SIRCs). According to Article 3 of the Malaysian Federal Constitution, all administrations pertaining to Islamic affairs are vested in Malay Rulers and their respective state governments. List II- State List (1) of the Ninth Schedule in the Constitution lists down all the Islamic matters that fall under the jurisdiction of the state which includes waqf (Rani \& Aziz, 2010).

There are fourteen states in the country. Every state established the SIRC in accordance with the state enactment which the main functions are to assist and advise the Malay Ruler and develop policies on matters pertaining to Islam. The laws pertaining to the administration of the Islamic affairs in the state, including the administration of waqf, are laid down in the Administration of The Religion of Islam Enactment of every SIRCs (Siraj, 2012). In order to execute the administration of waqf, the SIRCs have established a dedicated waqf unit or department in the council or an agency to run the administration of waqf within its jurisdiction (Sulaiman \& Zakari, 2015).

\section{Performance Measurement of Waqf Institutions}

This study focuses on the performance of waqf institutions in Malaysia. Since the main purpose of waqf is to fulfill non-profit purposes and its nature is similar to non-profit organizations (Ramli \& Muhamed, 2013), the definition and measurement of performance for the non-profit organizations will be applied to measure the performance of waqf institutions. In a related view, Ihsan and Ayedh (2015) suggested that waqf institutions have similar characteristics with non-profit organizations and can be considered in the same category, as the formation of these organizations is to benefit the society. Berman (2015, p. 5) defined 
performance as "the effective and efficient use of resources to achieve results and objectives". There has been argument on the measurement that relates to the performance of non-profit organizations (Epstein \& McFarlan, 2011) and particularly for waqf institutions. This is due to the complexity of the measurement as these organizations focus and emphasize on achieving their missions in which the accomplishments are difficult to measure. Fishel (2003) posited that the measurement has to consider the formation of the organization enables to achieve social, cultural, welfare or religious objectives. In general, the performance measurement of any organization in the social sector should be driven by its mission and goals (Ebrahim \& Rangan, 2014). Based on the argument, it can be said that performance measurement is very close and directly related to the objectives of an organization.

A recent study by Lee and Nowell (2015) on performance measurement for non-profit organizations, identified various perspectives that can be adopted in measuring and conceptualizing performance of the non-profit organization. The perspectives are inputs, organizational capacity, outputs, outcomes, public value accomplishments and network/ institutional legitimacy. These perspectives offer valuable insight for waqf institutions to measure their performance based on nonfinancial measurements. Therefore, the relevant perspectives of waqf performance measurement adapted in this study are input, output, outcome and network.

Input refers to the resources that are dedicated to the operation, and is necessary for producing goods and delivering services of any organization. In this context, financial and non-financial resources are being acquired and utilized efficiently in order to ensure sustainability, and support the operation in achieving the objectives of the organization (Helmig, Ingerfurth, \& Pinz, 2014). Output refers to the goods and services that resulted from the organization's activities (Cordery \&
Sinclair, 2013). This perspective measures the effectiveness in managing inputs that are related with the accomplishment (Berman, 2015) and associated with the short term objectives (Mitchell, 2012) of the organization. Outcome is defined as the effects and impacts of the goods and services delivered by an organization on the beneficiaries, (Cordery \& Sinclair, 2013) and normally related with the long term goal of the organization (Mitchell, 2012). Network denotes how well an organization manages its relationship with other parties and forms a reputation for trustworthiness and excellence within the network (Lee \& Nowell, 2015). This includes collaborating with other organizations which helps to reduce cost and duplication of efforts (Guo \& Acar, 2005).

\section{Maqasid Waqf}

The formulation of performance measurement for waqf institutions needs to be guided by the objectives or maqasid of waqf. Maqasid derived from the word Maqasa or Qasad which means objective, goal, aim, resolution, purpose, design, intent, intention or destination (Cowan, 1980, p. 767). Maqasid waqf signifies that the ultimate aim of waqf is doing good deeds for the sake of Allah SWT (Mahmud \& Shah, 2010). The terms relate with maqasid shariah which means the objectives of the divine law from Allah SWT. According to Imam al-Ghazali, "the objective of the Shari'ah is to promote the well-being of all mankind, which lies in safeguarding their faith (din), their human self (nafs), their intellect ( $a q l$ ), their posterity (nasl) and their wealth ( $\mathrm{mal})$ ". The majority of Islamic scholars agree that the basic objectives of shariah are for maslahah which means to preserve public good, establish justice and prevent vices or corruption (Chapra, 1996).

According to Al-Shatibi, who closely followed al-Gazali taxonomy, there are three main classifications of maslahah, namely, necessities (daruriyyat), needs (hajiyyat) and embellishment (tahsiniyyat). Daruriyyat involves the protection of basic necessities 
needed by the society which includes faith, life, intellect, posterity and wealth. The absence of these elements may lead to destruction of the society. Hajiyyat refers to the complementary that facilitate the necessities in order to avoid hardship, distress and predicament though the non-existence of the elements do not lead to destruction. Tahsiniyyat denotes the interest that lead to the enhancement of manners and mores of the society. It's absence, however, neither lead to destruction or hardship to the life of the society (Dusuki \& Abdullah, 2007).

In the context of waqf, the overall management of waqf has to take into consideration of maqasid waqf Laldin, Mahmud, Sawari, and Fuad (2012) opined that maqasid waqf covers the overall maslahah for the society and does not confine to any specific good deeds. Waqf also plays an important role in preserving daruriyyat, hajiyyat and tahsiniyyat. Among the issues that relate with the maqasid waqaf, as discussed by him, are the needs and priorities of waqf investment, continuous monitoring of waqf assets and replacement of waqf assets (istibdal). On the other hand, Ibrahim and Khan (2015) focus on the preservation of waqf properties which include protection from harm and destruction, illegal occupation, freedom from corruption, ensuring transparency and accountability, and fulfillment of conditions in waqf agreement. Other objectives of waqf as highlighted by AlMubarak (2016) are safeguarding the perpetuity of waqf by ensuring the economic activities should be sustainable, efficient, economically viable and profitable, equitable distribution of wealth and contribution to the construction of civilization.

The maqasid waqf discussed above will be integrated with the performance measurement dimensions adapted in this study. This integration will allow waqf institutions performance to be assessed with comprehensive, fair and holistic measurements.

\section{Methodology}

This study first reviewed literature from the works of previous scholars in order to gain an insight on waqf, the administration of waqf institutions, organizational performance measurement, and maqasid waqf.

The second stage of the study utilized the qualitative method to explore the ideal waqf performance measurement indicators based on the perspectives of waqf institutions. Data was collected through face to face semi-structured interview with waqf managers and an Islamic scholar. By utilizing purposive sampling (Sekaran \& Bougie, 2013), the interviewees comprised of the heads of waqf department from selected waqf institutions (2 participants). Apart from these experts, an Islamic scholar was interviewed to gain the insight of maqasid waqf elements that can be incorporated into the performance measurement dimensions.

All interviews were recorded with the permission of the participants and transcribed immediately in order to ensure the accuracy and validity of the data (Perakyla, 1997). Data gathered from the interviews was analyzed through thematic coding (Boyatzis, 1998) of three concurrent flows of activities: data reduction, data display and the drawing of the conclusion (Miles \& Huberman, 1994). NVivo 10 software was used in the data analysis process. The findings from the interview data analysis were used to identify the indicators as well as the formulation of the initial draft of the performance measurement model for waqf institutions.

\section{Results and Discussion}

\section{Discussion of Interview Findings}

The analysis of the interview revealed the existing practice of performance measurement in waqf institutions, the indicators as suggested by waqf managers and the overview of maqasid waqf. There is an agreement among the managers and the Islamic scholar that the management of 
waqf should take into consideration the elements of maqasid waqf.

\section{Waqf Managers}

We don't have any specific performance measurement for the overall waqf management. But we have SKT (Sasaran Kerja Tahunan) for every department and individual staff to achieve and used in the staff appraisal at the end of the year.

\section{... I think we need to have a performance measurement system, a framework in which we can measure the performance, for example the land registration, promotion, collection and distribution of waqf.}

The above interviews indicate that at present, waqf institutions do not evaluate the overall performance of waqf management as there is no specific evaluation instrument for them to adopt. In particular, the manager suggested that there is a need to have a specific performance measurement system in which the management of waqf can be measured. Therefore, the model proposed in this study can be adapted by waqf institutions to facilitate them to measure their performance and take necessary action for improvement.

The objectives of waqf institutions is to add value to waqf assets and the management of waqf, to inculcate religious endowment practices among the society towards the socio economic development of the ummah, based on sharia (Islamic law). ... in any waqf assets development, we need to observe the shariah.

The above statement infers that waqf institutions also have to comply with the shariah in every aspect of theirs activities in achieving the objectives.

Based on further interviews, both waqf managers proposed the following performance measurement indicators that can be used to assess the management of waqf. The indicators are depicted in Table 1. 
Table 1: The Dimensions and Indicators of Performance Measurement for Waqf Institutions

\begin{tabular}{|c|c|c|c|}
\hline No & Dimensions & Items & Indicators \\
\hline \multirow[t]{28}{*}{1.} & \multirow[t]{28}{*}{ Input/Resources } & \multirow[t]{12}{*}{ Waqf Land and Premises } & Registration of waqf land \\
\hline & & & Profiling of waqf land \\
\hline & & & Valuation of waqf properties \\
\hline & & & $\begin{array}{l}\text { Categorization of land based on type (specific or general waqf)/intention } \\
\text { of waqif/value }\end{array}$ \\
\hline & & & Prepare Waqf Land Development Plan \\
\hline & & & Waqf land bank through waqf Irsod (land given by the government) \\
\hline & & & Maintenance of waqf land \\
\hline & & & Prevention of intrusion on waqf land \\
\hline & & & Waqf land need to be gazette \\
\hline & & & Development of waqf land \\
\hline & & & Fulfill the intention of waqif \\
\hline & & & $\begin{array}{l}\text { Istibdal - Replacement of properties with money or other properties with } \\
\text { the same or higher value }\end{array}$ \\
\hline & & \multirow[t]{5}{*}{ Cash Waqf } & Marketing strategy through \\
\hline & & & Methods of collection \\
\hline & & & Increase in waqf cash collection \\
\hline & & & Investment of cash waqf \\
\hline & & & Distribution/utilization of cash waqf \\
\hline & & \multirow[t]{4}{*}{ Funding } & Availability of fund for $w a q f$ assets development \\
\hline & & & Availability of fund to run the operation \\
\hline & & & Revenue provision for mutawalli \\
\hline & & & Cost control \\
\hline & & \multirow[t]{7}{*}{ Human Resources } & Adequate number of staff \\
\hline & & & Adequate qualified staff \\
\hline & & & Adequate training for the staff \\
\hline & & & Adequate technical staff \\
\hline & & & Staff motivation \\
\hline & & & Staff qualification match with the job \\
\hline & & & Suitable remuneration scheme for the staff \\
\hline \multirow[t]{13}{*}{2.} & \multirow{13}{*}{$\begin{array}{l}\text { Output/ } \\
\text { Services }\end{array}$} & \multirow[t]{2}{*}{ Waqf Land } & Fulfill the intention of waqif \\
\hline & & & Distribution of usufruct (benefits) to the beneficiaries \\
\hline & & \multirow[t]{7}{*}{ Waqf Premises } & Maintenance of waqf premises \\
\hline & & & Rent or lease out waqf premises \\
\hline & & & Proper and complete rental agreement \\
\hline & & & Reasonable rental rate \\
\hline & & & Rental income collection \\
\hline & & & Collection of rental arrears \\
\hline & & & Build affordable houses for the people \\
\hline & & \multirow{2}{*}{$\begin{array}{l}\text { Education on waqf to the } \\
\text { society }\end{array}$} & Organize waqf awareness program \\
\hline & & & Publicity on waqf activities and achievement \\
\hline & & Customer & Customers satisfaction \\
\hline & & & Customers complaint \\
\hline \multirow[t]{2}{*}{3.} & \multirow[t]{2}{*}{ Impact } & \multirow[t]{2}{*}{ On the Society } & Public awareness on waqf \\
\hline & & & Public participant on waqf \\
\hline
\end{tabular}




\begin{tabular}{|c|c|c|c|}
\hline No & Dimensions & Items & Indicators \\
\hline \multirow[t]{6}{*}{4.} & \multirow[t]{6}{*}{$\begin{array}{l}\text { Network/ } \\
\text { Collaboration }\end{array}$} & \multirow[t]{4}{*}{ Government Departments } & $\begin{array}{l}\text { JAWHAR } \\
\text { - To facilitate and coordinate waqf institutions } \\
\text { - Government funding }\end{array}$ \\
\hline & & & State government \\
\hline & & & $\begin{array}{l}\text { Land office } \\
\text { - Waqf land registration }\end{array}$ \\
\hline & & & $\begin{array}{l}\text { Jabatan Penilaian Negara } \\
\text { - Valuation of waqf properties }\end{array}$ \\
\hline & & Government Agencies & $\begin{array}{l}\text { Yayasan Wakaf Malaysia } \\
\text { - Collection of cash waqf through salary deduction } \\
\text { - Development of waqf properties }\end{array}$ \\
\hline & & Other Institutions & $\begin{array}{l}\text { University - in doing research and development, waqf education } \\
\text { Corporations - Corporate waqf } \\
\text { Hospital - waqf clinic } \\
\text { Mosque - service center for waqf } \\
\text { Developer - waqf asset development } \\
\text { Financial institutions - finance waqf projects }\end{array}$ \\
\hline
\end{tabular}

\section{Islamic Scholar}

Waqf is discussed in the book of fiqh, in the field of shariah. So it is consistent with the requirements of shariah, the purpose and objective of shariah.. What is the purpose of Allah to reveal the shariah, the Islamic law, the Quran? It is to protect the religion of Islam. Therefore the purpose of waqf is also to protect the faith, life, intellect, ancestry, wealth and wealth. It does not confine only to the protection of wealth.

Among the examples, waqf land is used to build mosques for congregation prayers and establish strong unity among the society. Strong and united society will be able to preserve the religion. If we build waqf hospitals, this will provide health and medical care, nurture our children and elders for free. The purpose of waqf is also to preserve the intellect and advancing knowledge. University al Azhar is a waqf university and has been producing a number of Islamic scholars.

In term of priority, the utilization of waqf assets needs to fulfill the Daruriyyat, the basic necessities first, then followed by any complimentary and enhancement matters
The above interviews are consistent with AlMubarak, (2016) who suggested that maqasid waqf falls under the specific category of maqasid muamalat which is part of the maqasid shariah. Laldin et al. (2012) also pointed out that the maqasid waqf should cover the overall maslahah that are to protect religion, life, intellect, property and posterity. The execution of any waqf activities must be in accordance with the priority of daruriyyat, hajiyyat and tahsiniyyat.

Mutawalli has to observe the intention of waqif on the waqf assets. If there is a need to utilize the asset not in accordance with waqif intention, mutawalli has to negotiate with him. Based on the hukum (rule), the mutawalli cannot force the waqif to change his intention.

Waqf institutions need to ensure that the management of waqf must follow the hukum (stipulated rules) especially with regards to the fulfillment of waqif's intention. Overall, the analysis of the interview revealed the following considerations in relation to the existing practice of performance measurement in waqf institutions, the indicators as suggested by waqf managers, the need to observe the shariah and the overview of maqasid waqf. There is an 
agreement among the managers and the Islamic scholar that the management of waqf should take into consideration the elements of maqasid waqf and shariah compliance.

\section{Development of Performance Measurement Model for Waqf Institutions}

Based on the extensive literature review and the interviews with the waqf managers and the Islamic scholar, the draft of performance measurement model for waqf institutions is formulated and shown in Figure 1, below:

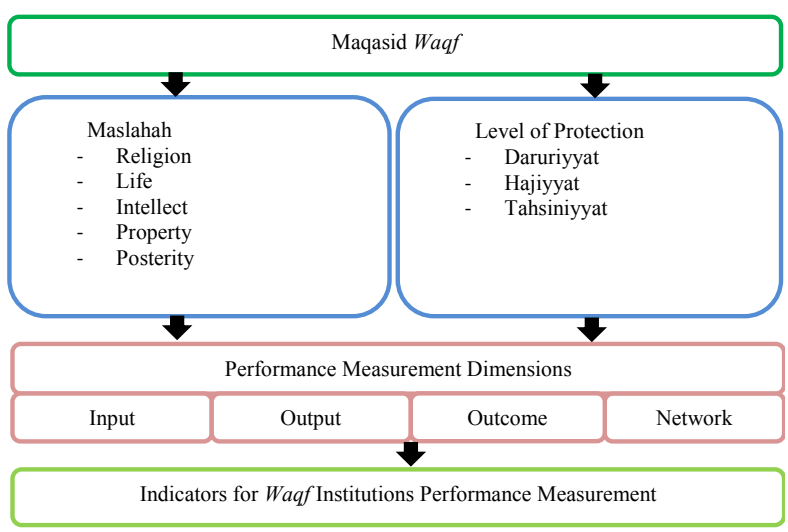

Figure 1: Performance Measurement Model for Waqf Institutions

In this model, it is suggested that the maqasid waqf be incorporated into the dimensions of performance measurement and form the overall performance measurement practices for waqf institutions. This is because the maqasid of waqf covers the overall maslahah and is not confine to the protection of wealth (Laldin et al., 2012). According to Laldin et al. (2012), waqf management to be undertaken by waqf institutions should be prioritized in accordance with the level of protection that are daruriyyat, hajiyyat and tahsiniyyat. Every dimension of the performance measurement will take into consideration the elements of maslahah that are the protection of religion, life, intellect, property and posterity. The dimensions and indicators derived from the non-profit organization performance measurement studies and results of the interviews. The dimensions are classified into input, output, outcome and network, which denote the important areas that should encompass the performance measurement.

Input refers to the resources that are dedicated to the activities of waqf institutions and necessary in delivering services to the society. This dimension focus on how the institutions acquire and utilize the resources to support their operation, in achieving their objectives (Connolly \& Hyndman, 2004). Among the resources are waqf land and premises, cash waqf, waqf fund and staff that relate to the management of waqf. These are the resources that waqf institutions are obliged to take care in accordance with the mission, objectives and functions of the institutions. Among the indicators to measure the performance of resources management, is waqf properties are registered under the name of the institutions in order to protect the ownership and perpetuity of the properties. The institutions need to gazette the properties as required by Waqf Enactment. The utilization and development of the waqf assets have to take into consideration the intention of waqif and the needs of the society in accordance with the priority.

Output indicates the services rendered by waqf institutions to beneficiaries and society at large (Mitchell, 2012). The services include rental of waqf properties, providing affordable residential and public facilities, and educate the society on the significance of waqf in Islam. Among the measurements of these services is the fulfillment of waqif intention on utilization waqf properties, as required by the shariah (rule) and distribution of the usufruct (benefit derived from waqf assets) to the maukuf-alaih (beneficiaries) in accordance with the agreed allocation. Education on the importance of waqf plays a role not only in creating awareness and encouraging participation from the society, but also to strengthen their faith in Allah SWT. Based on surah Al-Imran:92 in the Al-Quran, Al-Mubarak (2016) suggests that one of the main maqasid waqf is to purify one's heart by avoiding greed, selfishness and willing to sacrifice his best possessions in exchange 
for the pleasure of Allah. Therefore waqf institutions need to enhance and strengthen their waqf awareness program in order to educate the society on the significance of waqf and encourage them to participate in waqf activities.

Outcome is defined as the effects and impact of the good and services delivered by an organization on the beneficiaries (Cordery \& Sinclair, 2013) and normally related with the long-term goal of the organization (Mitchell, 2012). This dimension signifies the changes in behavior and environment of the intended population resulted from goods and services rendered by the organization (Epstein \& McFarlan, 2011). The impact is measured by comparing the level of the attribute of beneficiaries or population before and after they received the goods and services in order to know the effectiveness of the organization's activities (MacIndoe \& Barman, 2012). Waqf can give great impact on the social and economic wellbeing to society if it being efficiently and effectively managed. This has been proven during the Ottoman period where health, education, and welfare were financed by waqf (Toraman, Tuncsiper, \& Yilmaz, 2007). However, according to one of the interview participants, at present, waqf in Malaysia is at the stage of revitalization. Therefore, the impact of waqf on the society has yet to be seen. It has been suggested that at present, the impact can be measured based on the growth of awareness and participation of the public in waqf activities.

Network focuses on how an organization maintain a positive relationship and establish a reputation with the stakeholders and other organizations (Lee \& Nowell, 2015). This can be done by establishing collaboration between one institution with another. Collaboration helps in eliminating duplication of function and subsequently reduce costs (Guo \& Acar, 2005). Waqf institutions can collaborate with the institutions who have the same objectives or having the resources that they can share and utilize. Among the institutions that can collaborate with waqf institutions are the government departments, government agencies, financial institutions, corporations, universities, hospitals and mosques. For example, waqf institutions can collaborate with government departments to facilitate the registration and valuation of waqf land, financial institutions to finance waqf projects, corporations to generate waqf fund through corporate cash waqf and mosque to provide better and easy excess of services to the society.

The performance measurement model developed in this study will become a tool for waqf institutions to know the extent of their performance and facilitate them to take necessary action for improvement. The indicators identified in the study become the best practices and benchmark for them to manage their activities in achieving their objective, mission, and vision. The integration of Islamic elements in any management practices may provide a holistic and better guideline for Islamic institutions to execute the responsibility entrusted to them. Therefore, the incorporation of performance measurement indicators with the elements of maqasid waqf provides a comprehensive and holistic performance measurement model for waqf institutions.

\section{Conclusion}

This research explores the indicators of performance measurement for waqf institutions from the perspectives of waqf managers in Malaysia. The indicators provide an insight in formulating a holistic performance measurement model by incorporating performance dimensions from the non-profit organization practices and the elements of maqasid waqf. The dimensions are input, output, outcome and network. Every dimension takes into considerationthe maqasid waqf element that is to protect religion, life, intellect, posterity, and wealth in accordance with the priority of daruriyyat, hajiyyat and tahsiniyyat. It is important to incorporate these elements because waqf is a way of submission to Allah SWT and enshrined within the Quran and Sunnah. Thus, the conduct of waqf activities should be in line with Islamic principles and 
values. The performance measures developed fill the current gap in measuring the performance of waqf institutions where the current performance measures lack the integration of the maqasid element.

The performance measurement model developed in this study can become a self-assessment and self-improvement tool for waqf institutions to optimize their management of waqf assets. More importantly, the incorporation of maqasid element provides an appropriate measurement tool that can guide waqf institutions to carry out their responsibilities entrusted to them and discharge their accountability to the stakeholders. In addition, relevant monitoring authorities will also be able to use more appropriate performance measures in monitoring and providing relevant capability trainings of waqf institutions. However, the findings of this study are limited to the small number of participants in the data collection process. Future research can be enhanced by more comprehensive data collection in order to have a more accurate and comprehensive findings that can strengthen the formulation of the model. The proposed model has the potential to be adapted to other organisations where the measurement of maqasid element is applicable.

\section{References}

Ahmad, S., \& Muhamed, N. D. (2011). Institusi Wakaf dan Pembangunan Ekonomi Negara: Kes Pembangunan Tanah Wakaf di Malaysia. Paper presented at the Persidangan Kebangsaan Ekonomi Malaysia ke VI (PERKEM VI), Melaka, Malaysia.

Al-Mubarak, T. (2016). The Maqasid Of Zakah And Awqaf And Their Roles In Inclusive Finance. Islam and Civilisational Renewal (ICR), 7(2).

Auditor General's Report. (2014). The Activities Of The Departments/ Agencies And Management of State Government's Companies.
National Audit Department Malaysia.

Berman, E. (2015). Performance And Productivity In Public And Nonprofit Organizations (2 ed.). London and New York: Routledge.

Bernama. (2011). Agong Rasmi Hotel Wakaf Pertama Di Malaysia Bernilai RM256.4 Juta. BERNAMA.

Boyatzis, R. E. (1998). Transforming Qualitative Information: Thematic Analysis And Code Development. Thoussand Oak, California: SAGE Publication Inc.

Chapra, M. U. (1996). Objectives Of The Islamic Economic Order. London: Islamic Foundation.

Chin, J. (2015, 21 May ). 11th Malaysia Plan: Enhancing Bumiputera Economic Community Opportunities, Business News. The Star Online.

Connolly, C., \& Hyndman, N. (2004). Performance Reporting: A Comparative Study Of British And Irish Charities. The British Accounting Review, 36(2), 127-154.

Cordery, C., \& Sinclair, R. (2013). Measuring Performance In The Third Sector. Qualitative Research in Accounting \& Management, 10(3/4), 196-212.

Cowan, J. M. (1980). Hans Wehr: A Dictionary of Modern Written Arabic (Arabic-Ennglish).

Dusuki, A. W., \& Abdullah, N. I. (2007). Maqasid al-Shari'ah, Maslahah, and Corporate Social Responsibility. The American Journal of Islamic Social Sciences, 24(1).

Ebrahim, A., \& Rangan, V. K. (2014). What Impact? A Framework For Measuring The Scale And Scope Of Social Performance. California Management Review, 56(3), 118-141.

Epstein, M. J., \& McFarlan, F. W. (2011). Measuring The Efficiency And Effectiveness Of 
A Nonprofit's Performance. Strategic finance, 93(4), 27-35.

Fishel, D. (2003). Performance and Accountability in the Non-profit Sector. Keeping good companies, 55(9), 537.

Guo, C., \& Acar, M. (2005). Understanding Collaboration Among Nonprofit Organizations: Combining Resource Dependency, Institutional, And Network Perspectives. Nonprofit and Voluntary Sector Quarterly, 34(3), 340-361.

Hassan,A., \& Shahid, M.A. (2010). Management And Development Of The Awqaf Assets. Paper presented at the Seventh International Conference - The Tawhidi Epistemology: Zakat and Waqf Economy, Bangi.

Helmig, B., Ingerfurth, S., \& Pinz, A. (2014). Success and Failure of Nonprofit Organizations: Theoretical Foundations, Empirical Evidence, and Future Research. Voluntas (Manchester, England), 25(6), 1509-1538.

Ibrahim, A. A. M., \& Khan, S. H. (2015). Waqf Management In Bangladesh: An Analysis From Maqasid Al-Shar 'Ah Perspective. Paper presented at the International Conference on Maqasid al-Shari'ah in Public Policy and Governance, Kuala Lumpur, Malaysia.

Ihsan, H., \& Ayedh, A. (2015). A Proposed Framework of Islamic Governance for Awqaf. Journal of Islamic Economics, Banking and Finance, 11(2).

Isamail, M. Z., Rosele, M. I., \& Ramli, M. A. (2015). Pemerkasaan Wakaf Di Malaysia: Satu Sorotan. Labuan e-Journal of Muamalat and Society, 9, 1-13.

Kahf, M. (2003). The Role Of Waqf In Improving The Ummah Welfare. Paper presented at the International Seminar on "Waqf as a Private Legal Body," organized by Islamic University of North Sumatra, Medan, Indonesia.
Laldin, M. A., \& Hafas, F. (2013). Developing Islamic Finance In The Framework Of Maqasid Al-Shari'ah. International Journal of Islamic and Middle Eastern Finance and Management, 6(4), 278-289.

Laldin, M. A., Mahmud, M. W., Sawari, M., \& Fuad, M. (2012). Maqasid Al-Shariah Dalam Perlaksanaan Waqaf. Paper presented at the National Waqf Convention organized by the Prime Minister's Department Waqf, Zakat and Hajj Department, Kuala Lumpur.

Lee, C., \& Nowell, B. (2015). A Framework For Assessing The Performance Of Nonprofit Organizations. American Journal of Evaluation, 36(3), 299-319.

MacIndoe, H., \& Barman, E. (2012). How Organizational Stakeholders Shape Performance Measurement In Nonprofits: Exploring A Multidimensional Measure. Nonprofit and Voluntary Sector Quarterly.

Mahamood, S. M. (2000). The Administration Of Waqf, Pious Endowment In Islam: A Critical Study Of The Role Of The State Islamic Religious Councils As The Sole Trustees Of A Wqaf Assets And The Implementation Of Istibdal In Malaysia With Special Reference To The Federal Territory Of Kuala Lumpur. (PHD), Birmingham University.

Mahmud, M. W., \& Shah, S. S. (2010). Optimization of Philanthropic Waqf: The Need for Maqasid-based Legislative Strategies. Shariah Law Reports, 2, 45-29.

Miles, M. B., \& Huberman, A. M. (1994). Qualitative Data Analysis: An Expanded Sourcebook (2 ed.). United States of America: SAGE Publication Inc. 
Mitchell, G. E. (2012). The Construct of Organizational Effectiveness: Perspectives From Leaders of International Nonprofits in the United States. Nonprofit and Voluntary Sector Quarterly, 42(2), 324-345.

Omar, I. (2016, 26 February). Wakaf Tanah Untuk Rumah Rakyat. Utusan Malaysia.

Perakyla, A. (1997). Reliability And Validity In Research Based On Tapes And Transcripts. Qualitative research: Theory, method and practice.

Ramli, N. M., \& Muhamed, N. A. (2013). Good Governance Framework for Corporate Waqf: Towards Accountability Enhancement. Paper presented at the World Universities' Islamic Philanthropy Conference, Kuala Lumpur, Malaysia.

Rani, M. A. M., \& Aziz, A. A. (2010). Waqf Management And Administration In Malaysia: Its Implementation From The Perspective Of Islamic Law. Malaysian Accounting Review, 9(2), 115-121.
Sabiq, A. S. (2004). Fiqh el Sunnah. Mesir: Al Fath lil I'lam el Arabi.

Sekaran, U., \& Bougie, R. (2013). Research Methods for Business A Skill-Buiding Approach (6 ed.). United Kingdom: Wiley.

Siraj, S. A. (2012). An Empirical Investigation Into The Accounting, Accountability and Effectiveness of Waqf Management In The State Islamic Religious Councils (SIRCs) In Malaysia. (Thesis), Cardiff University.

Sulaiman, M., \& Zakari, M. A. (2015). Efficiency and Effectiveness of Waqf Institutions in Malaysia: Toward Financial Sustainability. Bloomsbury Qatar Foundation Journals, 1, 4353.

Toraman, C., Tuncsiper, B., \& Yilmaz, S. (2007). Cash Awqaf in the Ottomans as Philanthropic Foundations And Their Accounting Practices. Paper presented at the Fifth Accounting History International Conference, Banff, Canada. 
